\title{
Review \\ Beyond the Screen: Violence and Aggression towards Women within an Excepted Online Space
}

\author{
Shireen Bernstein ${ }^{1, *(\mathbb{D})}$, Wayne A. Warburton ${ }^{1} \mathbb{C}$, Kay Bussey ${ }^{2} \mathbb{C}$ and Naomi Sweller ${ }^{1}$ (I) \\ 1 School of Psychological Sciences, Faculty of Medicine, Health and Human Sciences, Macquarie University, \\ Sydney, NSW 2109, Australia; wayne.warburton@mq.edu.au (W.A.W.); naomi.sweller@mq.edu.au (N.S.) \\ 2 Centre for Emotional Health, School of Psychological Sciences, Faculty of Medicine, Health and \\ Human Sciences, Macquarie University, Sydney, NSW 2109, Australia; kay.bussey@mq.edu.au \\ * Correspondence: shireen.bernstein@students.mq.edu.au
}

Citation: Bernstein, S.; Warburton, W.A.; Bussey, K.; Sweller, N. Beyond the Screen: Violence and Aggression towards Women within an Excepted Online Space. Sexes 2022, 3, 78-96. https://doi.org/10.3390/sexes3010007

Academic Editor: Joana Carvalho

Received: 15 December 2021

Accepted: 18 January 2022

Published: 21 January 2022

Publisher's Note: MDPI stays neutral with regard to jurisdictional claims in published maps and institutional affiliations.

Copyright: (c) 2022 by the authors. Licensee MDPI, Basel, Switzerland. This article is an open access article distributed under the terms and conditions of the Creative Commons Attribution (CC BY) license (https:/ / creativecommons.org/licenses/by/ $4.0 /)$.

\begin{abstract}
This theoretical review explores the possibility that the consumption of internet pornography (IP) represents a credible risk factor in the perpetration of aggression and violence against women. Sexual violence, abuse, and degradation of women is commonly depicted in mainstream heterosexual IP. Despite the violent tenor, the effect this material may have on beliefs, attitudes and behaviors is understudied, as are the reasons why violent and degrading IP is so widely viewed, enjoyed, and accepted. Both theory and empirical findings support the contention that depictions of violence in IP may contribute to real world aggression and violence against women, with two relevant spheres of inquiry proposed in this theoretical review. The first considers IP as a 'zone of cultural exception', in which the perpetration of violent and degrading acts against women are eroticized and celebrated, despite such behaviors being considered antisocial in wider society. It is suggested that this excepted status is enabled by the operation of the third person effect to negate the detrimental effects of IP. The second explores the objectification and dehumanization of women in IP and the use of moral disengagement by viewers to enable their disavowal of any harm in the depicted violence.
\end{abstract}

Keywords: internet pornography; gendered violence; media violence; sexual objectification; dehumanization

\section{Introduction}

The structural conditions that contribute to an environment that fosters violence against women are complex and multifactorial, and whilst no single factor can be implicated, the social influence of the media remains an area of both significance and debate. Consumption of internet pornography (IP) including its use by young people, is widespread and increasingly normative [1-3]. Behavior that is eroticized and normalized is germane, and thus the acts depicted in IP, like any social behavior, must be understood within the cultural context in which they are performed [4]. It is therefore notable that mainstream heterosexual IP commonly depicts sexual and physical violence, coercion, and degradation, including slapping, choking, gagging, ejaculating on, verbal abuse, and aggressive multiple penetrations of women [5-8]. Numerous meta-analytic reviews, commissioned reports and longitudinal studies have reported relationships between violent media exposure and aggressive thoughts, feelings, and behavior [9-14]. There are, however, limited studies examining whether IP, which often depicts aggressive and violent sexual conduct towards women [8,15-17], also impacts thoughts and behavior, specifically aggression and violence toward women. It is also unclear why this IP narrative of hostile and humiliating acts against women is so widely reproduced and watched.

This theoretical review seeks to explore how conduct that is broadly denounced in contemporary society, is nevertheless freely depicted in IP, effectively facilitating the creation of an excepted online space in which social proscriptions against aggression and violence towards women are effectively abandoned [18]. The theoretical approach in this 
review follows the objective of elucidating and verifying the identified phenomenon of IP as a 'zone of cultural exception' [18]. Some scholars also suggest that cognitive distortions, in relation to the depicted sexual acts, may assist some individuals to morally disengage from personal and social censure and deny any harm in the depicted conduct [19]. Thus, it is appropriate to consider how aggressive and violent IP might assist to culturally sanction aggression and violence against women beyond the screen.

\subsection{Violence against Women: Offline and Online}

Violence against women is a widespread and intractable social issue. The World Health Organization (WHO) indicates that, worldwide, almost one third (27\%) of women aged 15-49 years who have been in a relationship report being subjected to some form of physical and/or sexual violence by their intimate partner. The WHO identifies violence against women as a result of factors occurring at individual, family, community, and wider society levels, which interact with each other to increase (or reduce) the risk of violence perpetration. Amongst the factors they identify as increasing risk they include, "harmful masculine behaviors, including having multiple partners or attitudes that condone violence (perpetration)"; and "community norms that privilege or ascribe higher status to men and lower status to women" as well as "ideologies of male sexual entitlement" [20]. In this context, it is critical to define and ascribe meaning to the acts commonly depicted in IP in order to better understand its effects.

Physical violence is defined as including "slaps, hits, punches, being pushed down stairs or across a room, choking and burns, as well as the use of knives, firearms and other weapons". Sexual violence is defined as including "rape, sexual abuse, unwanted sexual advances or harassment and intimidation at work and elsewhere, being forced to watch or engage in pornography, sexual coercion, having sexual intercourse out of fear of what a partner might do, forced prostitution, and human trafficking" [21]. Globally, as many as $38 \%$ of all murders of women are committed by intimate partners, and in the US, nearly half of all female homicide victims were killed by a current or former dating partner [22]. In Australia, an average of one woman a week is murdered by her current or former partner [23]. In the European Union, over a third (37\%) of physical violence against women takes place at home [24]. Sexual coercion (i.e., being forced or frightened into sexual activity) is also a substantial social concern in its own right. In the US National Youth Risk Behaviour survey, 10.7\% of high school girls reported having been forced to "do sexual things they did not want to" by someone they were dating or going out with in the preceding 12 months [25]. Similarly, in a representative sample of 20,094 Australian men and women (aged 16-69), 4.2\% of men and $22.4 \%$ of women reported having ever experienced sexual coercion [26].

\subsection{Focus and Definitions}

Viewing and engaging with IP is common and even normative $[1,27,28]$, with recent statistics from just one popular IP website, Pornhub, indicating that there were over 42 billion visits to their website in 2019 [29]. Consumption of IP is also not limited to adults, with $94 \%$ of UK adolescents surveyed indicating they had seen IP by 14 years of age [30], US research finding the average age of first exposure was 11 years of age [31], and Australian research showing the median age of first exposure was 13 years of age for men and 16 years of age for women [3]. It is clear that there are many genres of sexually explicit material online, and some studies find that viewing some content may assist to diminish sexual anxiety and dysfunction, encourage sexual expression, and provide entertainment and satisfaction $[32,33]$. Pornography use has also been shown to have self-perceived benefits for adults such as feeling more comfortable, empowered, and open-minded about sex and sexuality generally [34,35]. However, the focus of this review is not on erotica or other gender or sexuality positive content, but on mainstream, heterosexual IP that follows a prevailing narrative of dominant men and submissive women in sexual interactions characterized by manipulation, verbal and physical aggression, and degradation $[8,36,37]$. 
In this context, IP is defined as internet based, sexually explicit material (including both still and moving imagery and audio) displaying genitalia with the aim of sexual arousal or fantasy $[38,39]$. In addition, material previously considered marginal and arcane, including "gonzo" style IP involving particularly rough, aggressive, and demeaning acts, is increasingly the norm in mainstream heterosexual IP $[6,8,40]$. Content-based definitions of degrading pornography describe it as material that is sexually explicit and humiliates, debases, and dehumanizes people, in a manner that endorses such degradation [41].

\subsection{Media Violence and Its Effects}

Despite largely stipulatory recognition of the persuasive effects of advertising media on human behaviors such as food and alcohol consumption [42,43], or the educative benefits of educational media [44], the effect of media violence on human behavior is still much-contested. Some scholars suggest that the reported link between violent media content and aggression can be explained by Moral Panic Theory, whereby societies tend to vilify new forms of media and blame them for societal issues, until they become more familiar with and accepting of them [45]. In contrast, other scholars contend that violent media consumption, including IP, can have significant, measurable negative impacts for some users [46-50].

Researchers who question a causal link between media violence and aggression suggest that pre-existing aggressive traits may provide a better explanation both for the consumption of violent media and subsequent performance of aggressive behavior e.g., (e.g., [51-53]). Many of these researchers (e.g., [53-57]) also point to meta-analyses that find small effects on aggressive behavior, and assert a range of issues with research that concludes there is a connection between violent media consumption and aggressive behavior, including methodological issues in experiments and publication bias in meta-analyses (see: [58-61]). Such arguments have themselves been analyzed and contested by a number of media violence researchers (see: [62-64]), who point out that the well-understood processes of learning, desensitization and neural acquisition that underlie other media effects should also apply to violent and antisocial media [50]. Importantly, it is also recognized that media violence exposure alone is neither necessary nor sufficient to cause moderately aggressive or violent behavior [65]. However, it is possible that the risk of such behaviors may increase with an accumulation of risk factors (even factors with small-moderate effects), when these are not ameliorated by protective factors. This risk and resilience framework can be used to describe complex multicausal phenomena, such as societal aggression, by focusing on the pattern of inherent risk and protective factors at both an individual and societal level [66]. This approach has also previously been applied to exploring the developmental effects of media violence [67], and also seems appropriate for an examination of sexually aggressive IP.

\subsection{Aggression and Violence in IP}

Studies consistently find that women are more likely to be depicted in heterosexual IP as the victims of aggressive and degrading behaviors than men $[5,68,69]$. In a content analysis of 50 randomly selected films from the top 250 grossing pornography films of 2007, over 3300 different acts of verbal and physical aggression were recorded, and this aggression (largely perpetrated by male actors against female actors) was responded to with either neutral or pleasure expressions in over $95 \%$ of the scenes [5]. A more recent study of mainstream IP (derived from the five largest categories on Pornhub) similarly found that women were significantly more sexually objectified than men across a range of IP categories, and were significantly the normalized target of aggression [70].

However, other studies dispute any consistent increase in aggressive content over the past decade, arguing that the average IP video today contains shorter segments showing aggression, and that more violent content receives less positive reviews [71]. Similarly, McKee [72] found no gender differences in objectification in a sample of the 50 bestselling pornographic videos, although measures of violence were excluded from gendered 
comparison, as these were identified as "too uncommon in the sample to allow meaningful comparison of gender roles" (p. 288). It is worth noting, however, that this study was conducted some time ago, and based on a content analysis of commercially produced DVDs and videos [72], which are markedly different to the unrestricted content available on free IP websites. Other researchers describe aggressive "gonzo style" sex, commonly depicted in IP, as simply a preference for "unadulterated sex" and believe it is misleading to make generalisations about either IP or the motivations of viewers of IP [73,74]. McKee [75] has also pointed to methodological issues in the definition of aggression in IP content analyses studies $[5,76]$. Specifically, he argues that by not including consent in the definition of aggression, its level is overestimated. Thus, the definition of aggression by Baron \& Richardson [77] as "any form of behavior directed toward the goal of harming or injuring another living being who is motivated to avoid such treatment" is favored, because it includes 'motivation to avoid the treatment' in the definition. This would therefore exclude consensual hitting, slapping, hair pulling, and kicking from the definition of aggression because these are "requested actions" [75].

Regardless of whether or not such acts depicted in the context of an IP scene meet the criteria for being 'true aggression', the issue of dehumanization, degradation, and objectification remain, as does the key concern as to whether such material can influence the IP viewer to behave concomitantly in the real world. There is, similarly, some evidence that the behavior of female actors is not always as 'consensual' as it may appear [78], as IP producers sometimes use victims of sex trafficking to produce content [78-80]. Women are certainly capable of expressing valid consent to a range of sexual behaviors, however, even where IP actors do 'consent' to degrading and hurtful behavior, acquiescence, or willingness to accept clearly demeaning acts, such as ejaculating on a woman's face (EOWF) or performing oral sex immediately following anal penetration (ATM) is problematic, given many of these acts are recognized as both high risk and harmful to the health of performers [81].

\subsection{Effects of Aggression and Violence in IP}

A number of researchers propose that the tacit acceptance of violence depicted in IP not only reinforces that violence against women is tolerated or even desired by women, but also that women are somehow immune to acts of physical and verbal violence $[8,15,37,82]$. The influence of IP is however variable, and not all men positively appraise IP, with many actively rejecting it $[83,84]$. It has also been suggested that those more inclined to violence, or to use force in sexual relations, react more favorably to such material, as do those who endorse the underlying value system espoused by aggressive IP and therefore actively seek it out $[46,85,86]$. Nevertheless, there is empirical research suggesting a link between ongoing IP exposure and the way viewers subsequently think, act, and behave. Studies have found that frequent and routine viewing of IP may reinforce harmful gender stereotypes, contribute to the formation of unhealthy and sexist views of women and sex, and augment sexually aggressive attitudes and behaviors [40,49,87-94]. These views, however, are not unanimous $[95,96]$, and some authors contest any direct connection between IP consumption and actual sexual violence [74,97] with the debate ongoing [98,99].

Empirical studies have also indicated that the content viewed in IP is often a source of both sexual fantasizing and actual sexual behavior. This includes a study of heterosexual men's interest and engagement in a variety of dominant behaviors, which found that both interest in watching pornographic movies and more frequent consumption of pornography were associated with men's desire to engage in, or having already engaged in, behaviors such as hair pulling, spanking a partner hard enough to leave a mark, EOWF, confinement, double-penetration, slapping, choking, and verbal abuse [37]. Another study of young men found that almost all had consumed pornography, and 53\% felt that pornography inspired their sexual behavior [100]. Similarly, a study of young women's sexual behavior conducted at a sexual health clinic, found that four out of five women had consumed IP, and one-third of them believed that it had impacted their sexual behavior, sometimes 
inducing them to perform sexual acts they found negative or painful [101]. A qualitative study examining the act of EOWF exemplifies the influence of IP, with the study concluding that this act is utilized as a clear signal of male dominance and aggression rather than it serving to elicit any inherent sexual gratification, given it actually requires the interruption of sexual pleasure to complete the act [7].

The connection between IP and aggressive, gendered behavior has also been explored in relation to intimate partner violence (IPV). One study found that $39 \%$ of women experiencing IPV reported that their partners had forced them to act out pornographic scenes they had been shown, as compared to $3 \%$ of other women [102]. Another study of marital rape victims [103] similarly found that $14 \%$ of the 87 women interviewed had been forced to create pornographic material. Moreau [104] reported that amongst a sample of victims of IPV, $26 \%$ reported being victim of at least one incident related to pornography, and women who reported experiences associated with pornography were 12-20 times more likely to be victims of severe sexual violence. Using a logistic regression model, the use of alcohol and pornography together was also found to significantly increase the odds of a women experiencing IPV being sexually abused [92]. Similarly, a study which collected data regarding women's experiences of sexual violence and their abusers' use of pornography at a rape crisis center found that $28 \%$ of respondents reported that their abuser used pornography, and for $12 \%$ of the women, pornography was imitated during the abusive incident [105].

\subsection{Psychological Mechanisms That May Underlie the Influence of IP}

Social cognitive theory describes a mechanism by which individuals can acquire behavioral scripts by watching how others act and ascertaining the consequences and rewards of these behaviors [106]. The media has been identified as one instrument that can facilitate this learning process $[14,106,107]$. Beneath the wider social cognitive theory umbrella, social learning theory identifies the impact of aggressive media characters as role models, whose depicted actions may initiate observational learning [108]. This learning may encourage the acquisition of aggressive behavioral scripts and the enactment of observed aggressive behaviors, particularly when the media characters are rewarded for their aggressive behavior and the viewer admires or identifies with them $[108,109]$. Thus, it is plausible that when a male IP viewer is regularly exposed to IP narratives in which male protagonists satisfy their sexual desires, regardless (or even because) of the violence they employ, and they are rewarded with either submission or sexual arousal from female protagonists, learning will be reinforced [110,111]. Exposure to these sex-typed media characters combined with depictions of aggression against woman may also have a desensitizing effect on viewers. Studies suggest this desensitization may assist viewers to accept the violence depicted in IP, and in turn this may lead to sexual callousness, including towards victims of IPV [112-114]. A separate experimental study found that males who viewed sexual violence demonstrated higher scores on an acceptance of interpersonal violence measure and the rape myth, compared to males who had viewed a physically violent or neutral film [115].

Learning theories are also relevant in sexual scripting, as delineated in the $3 \mathrm{AM}$ acquisition, activation, and application model of sexual socialization [116]. Wright's model describes how through exposure to sexualized media content, previously unfamiliar or unknown sexual scripts may be acquired, latent sexual scripts may be activated, and previously obtained sexual scripts may be normalized and applied, both attitudinally and behaviorally [116]. The activation of a script occurs when media exposure provides a cue for retrieval, and this can involve a stimulus other than the original source of the script, including sexual arousal itself [116]. Importantly, higher order, abstract sexual scripts that transmit sexual attitudes, can also be absorbed from underlying themes in the content, and can also impact non-sexual attitudes toward women [117]. With this understanding, it is plausible that the learning and scripts acquired in IP are activated when an individual finds themselves aroused with their partner (as they have previously been aroused with IP), and that an IP-congruent script of gendered sexual relations may then be used to guide their 
beliefs, expectations, and behaviors $[110,118]$. These scripts may serve as frameworks for behavior and may or may not be conscious to the viewer [118]. The degree of influence of IP is also determined by the operation of various social, contextual, perceptive, cognitive, and motivational mechanisms as well as individual differences [119].

\section{IP Consumption and Aggression and Violence against Women: Two Hypotheses}

The link between IP and real-world gendered violence explored in this review is based on a theoretical approach grounded in social cognitive and script theory, and elucidated by two hypotheses. A comprehensive literature search was used in order to identify the studies to be included. The PsycINFO database was used, and the following search terms were entered: "internet pornography", "cultural exception", "objectification of women", "acceptance of sexual violence", "moral disengagement", "third person effect". The inclusion criteria were (1) publication in a peer-reviewed journal, (2) the study being based on empirical data or theory that was directly relevant to the hypotheses examined (i.e., articles that elucidated theoretical concepts such as zones of cultural exception or cognitive biases). The first hypothesis considers the notion that IP serves as a zone of cultural exception, set apart from prevailing social norms of sexual engagement, and facilitated by the operation of the third person effect, a perceptual bias that is not uncommon in relation to media effects [120]. The second hypothesis explores the use of moral disengagement by viewers [121], to facilitate the disavowal of any harm caused to the subordinated actor (usually women) by the aggressive and degrading acts frequently depicted in heterosexual IP [122]. This is explored in terms of the manner in which this type of IP diminishes, objectifies and dehumanizes women, and how this cognitive mechanism might also enable offline violence against women [82,123].

\subsection{Hypothesis 1 (H1). IP as a Zone of Cultural Exception and the Role of the Third Person Effect}

Atkinson \& Rodgers [18] describe IP as a "zone of cultural exception" in which "violence and harm is experienced, celebrated, or produced as part of new repertoires of exceptional social conduct ... " (p. 1291). The notion of "cultural exception" is used in this theoretical review to refer to the "ways in which certain networked media spaces offer the enactment or viewing of socially extreme conduct apparently without consequence or connection to everyday modes of social being and normative prescription" [18]. This concept builds on the work of Freud [124] and Elias [125] and their descriptions of the civilizing demands of society in which individual libidinal desires must be inhibited and regulated to mitigate the risk of interpersonal harm. Atkinson and Rodgers [18] suggest that both violent video games and violent IP have become the cultural conduit into which aggressive desires can be channeled and explored in a space excepted from the usual cultural and social restraints.

The authors [18] also reference the work of Elias [125], who suggested that 'civility' involved the sublimation of aggressive and sexual drives into art, books and sport. A core premise of Elias' 'civilizing process' theory is that guilt and the rejection of violent impulses are manifest in a society in which human beings are restricted in their ability to directly satisfy all their drives and passions [125]. Importantly, Elias' work suggested that the development of a civilized society is part of a long term and evolving historical process that is neither robust nor immutable, and this can be interrupted at any time. Atkinson and Rodgers reaffirm this ongoing dilemma, whereby individuals are confronted with the lure of opportunities to engage in sexually aggressive and violent experiences in popular culture and online arenas, despite the social and legal proscriptions against such violence in the offline world. Such opportunities to explore aggressive and violent erotic impulses are abundant within much heterosexual IP.

\subsubsection{Ubiquity of IP in Facilitating a Zone of Cultural Exception}

According to Atkinson and Rodgers [18], IP has facilitated the creation of an 'otherworldliness' in which all sexually violent, aggressive and demeaning acts can be viewed 
and engaged with, whilst the viewer is insulated from social and legal consequences. Unlike previous forms of pornography, IP is unique in its affordability, accessibility and anonymity [126]. Viewers can easily engage with IP without the usual censures of identifiability or guilt, because they can convince themselves that these spaces are separate from their offline world and thus exempt from scrutiny or consequence $[18,127]$. However, far from seeing this content as harmless fantasy, Atkinson and Rogers advocate reconsidering non-criminalized harm in terms of the way in which "image and screen cultures contribute to the 'cultural normalization' and commodification of violence, social harm and subjugation" and they suggest that "all forms of symbolic violence and humiliation, gendered and racial abuse, and sado-voyeurism" should be recognized as criminal behavior [18].

\subsubsection{IP and the Third Person Effect}

It is also possible that any cognitive dissonance experienced by viewers of aggressive or degrading IP may be effectively mitigated by cognitive distortions such as the third person effect (TPE), which is the tendency to believe that others are more susceptible to media messages than oneself [128-130]. This bias may go some of the way towards explaining the reticence of viewers to acknowledge the deleterious effects of IP. It has been hypothesized that there are two major components to the TPE: the perceptual component, and the behavioral component [131]. The perceptual component refers to the discrepancy whereby an individual estimates that the effect of a message will be greater on others than themselves [132]. The behavioral component refers to the tendency to react in a manner consistent with this perceptual discrepancy. For example, a person may support censorship of media content, believing others will be more affected by the content, whilst simultaneously believing themselves to be immune to such effects [131,132].

Perloff [128] has also described several factors that moderate the strength of the TPE, including the desirability of the message content, the social distance between self and other, and attributes of individuals and groups. The desirability of the message content is particularly relevant, as it has been suggested that messages perceived as undesirable will enhance TPEs [120]. In this way, socially unacceptable messages (such as those contained in IP), could be assessed as content that only susceptible "others" will internalize [133]. The social-distance factor suggests that as comparison others become more distant or psychologically removed from the self (usually facilitated via downward social comparison), the self-other discrepancy increases [134]. A study by Lo \& Wei [130] confirms this cognitive bias, finding that most respondents believed IP had a greater negative influence on others than on themselves, and female respondents perceived it to have more negative effects on males than other females. Similarly, a survey of U.S. and South Korean college students found $45.7 \%$ of participants anticipated a greater negative effect of IP on others than on themselves [132].

Thus, it seems reasonable to assume that many viewers of IP would rate themselves as unlikely to experience any negative consequences from their consumption, despite evidence suggesting that this material can have significant impacts on sexual scripting, sexual practices, and attitudes towards sexual coercion and consent $[90,110,135,136]$. This overestimation of individual inviolability to the persuasive aspects of IP, coupled with the demarcation of IP as an excluded zone, has a mutually reinforcing effect. Specifically, the systematic ways in which IP has been normalized and tolerated, regardless of its depiction of aggressive and degrading acts against women, facilitates a cultural environment in which violence against women is more acceptable and therefore more likely.

\subsection{Hypothesis 2 (H2). The Objectification and Dehumanization of Women in IP and the Role of Empathy and Moral Disengagement}

Fredrickson \& Roberts [137] define sexual objectification as the separation of a woman's body, body parts, or sexual functions from her personhood and delineate this concept two ways: direct and indirect objectification. Indirect objectification is conceptualized in terms of positioning the female body as an object for the gratification of the male gaze [137]. Direct 
objectification includes all forms of sexual victimization whereby a woman's body is treated as a mere instrument or thing [137]. It has been suggested that the degree of sexual objectification depicted in IP effectively reduces women to interchangeable body parts $[138,139]$ devoid of humanity, morality, or the capacity for complex mental thought [140-142]. This hypothesis has been tested in experimental studies involving the inversion effect, which refers to the finding that inverted stimuli are more difficult to recognize than upright ones. Specifically, the configural information processing hypothesis suggests that faces are processed with the use of configural information to form a holistic representation, whilst objects are processed in parts by their individual features [143]. Bernard [138] set out to test if sexualized males and females are both processed configurally, eliciting this effect, or if females are processed analytically as objects. As predicted, sexualized men were less well recognized when inverted, whereas this effect was absent for sexualized women, since they were simply perceived as inverted objects [138]. This effect is significant because when the sexual objectification of women is reflexive and unexceptional, tolerance of violence against women also becomes more culturally normative [144,145].

This effect has also been confirmed empirically, with links found between men's regular exposure to objectifying media and attitudes supportive of violence against women, mediated by perceptions of women as sex objects [16,91,123]. In IP this objectification is achieved by prioritizing female genitalia (often to the exclusion of her face), and is also exemplified by particular sexual acts, such as "when double penetration of a woman occurs, which suggests a woman's body is just a series of holes to be entered or when a woman's face or chest is ejaculated upon, suggesting a woman's body is simply an object to display the result of male pleasure instead of an embodiment of her own pleasure" [70]. Such conduct and other acts of dominance and aggression are commonly depicted in heterosexual IP. A content analysis of top selling IP videos by Bridges et al. [5] found that male actors ejaculated on their female partner's face in $63 \%$ of scenes, and $19 \%$ of scenes included the depiction of double penetration. Similarly, a comparative study of the objectification of males and females in 400 amateur and professional IP videos found that close-ups of female genitalia occurred in $61 \%$ of scenes, whilst a similar focus on males occurred only $19 \%$ of the time [146].

\subsubsection{How Objectification May Lead to Violence}

According to schema theory [147], objectifying attitudes towards women may generalize to become a stable part of an individual's attitudes, beliefs, and knowledge structures, influencing both their assessment of the status of women and cementing cognitive scripts about how women should be treated. The objectification of women has been found to be associated with greater acceptance and perpetration of sexual violence, including willingness to rape and sexually harass women, and to report negative attitudes toward female rape victims [91,148-150]. Thus, the sexual objectification of women may lead to violence both via the acquisition and activation of violent sexual scripts and by altering the prevailing cultural expectations of how women should be treated [40,123,150-152]. The deindividuation that occurs as a part of objectification also effectively facilitates dehumanization $[70,139,146]$. Studies have shown that objectified women are perceived as less human than non-objectified women, and they are consequently accorded less moral concern and acknowledgment of their cognitive capacities [123,145]. Relatedly, in an experimental study, Vasquez et al. [153] found that the objectification of a woman increased aggression toward her, even in the absence of any provocation. Importantly, this effect was noted using a real female target whom participants directly objectified, using a physical measure of aggression whereby participants believed that they were inflicting real pain on the woman. It is unclear however, whether violent-media exposure leads to aggressive behavior via dehumanization, or violent-media exposure leads to dehumanization via aggressive behavior. In either case, it is patent that denying another's humanity enables and disinhibits violent acts [154]. 
Similarly, 'excepted spaces' such as IP sites provide a vehicle for the expression and disowning of sadistic impulses, and permit viewers to consider IP not as a depiction of complete human beings, but as disarticulated 'part-objects' of manipulatable genitalia [122] Specifically, sexualized parts capture attention, whilst differentiating features, like faces, receive less attention. Thus, sexual objectification scholars $[155,156]$ posit that people, typically women, become sexually 'fungible' or interchangeable, and reduced to a set of sexualized body parts or functions that are easily replaced by another. Apart from the negative mental health effects caused by the deindividuation of the fungible individual, it has also been proposed that normal moral restraints against violence are weakened when a person is no longer perceived as a distinguishable individual, providing a foundation for acts of violence $[157,158]$. In this context, objectification may lead to violence by normalizing the depiction of women as erotic objects in the sexual service of men and by denuding women of their humanity, thus removing their right to any moral concern or empathy $[82,150]$.

\subsubsection{Empathy and Antisocial Behavior}

The impact of IP consumption may also be amplified by what has been described as a growing lack of empathic connection in contemporary society [159]. Empathy has been described as the social glue that holds society together [160] and without it, suffering becomes unremarkable. In the field of political conflict, scholars such as Orwin [161] warn that "The final pitfall of the new abundance of televised suffering is also the most ironic. It is the danger that constant exposure to such suffering will not sensitize but inure us to it". Bushman \& Anderson [162] similarly describe media-elicited desensitization as a process whereby viewers become "comfortably numb" to the pain and suffering of others. Relatedly, a comprehensive meta-analysis found that exposure to violent video games increased aggressive thoughts, angry feelings, physiologic arousal, hostile appraisals and aggressive behavior, and decreased prosocial behavior and empathy [9]. The reverse has also been shown, with prosocial media found to increase helping behavior and empathy $[11,163]$. The effect of media on thoughts and behaviors can have significant real-world consequences. Research undertaken across seven countries found that reduced empathy was one of the two key mediators through which exposure to media violence caused aggressive behavior [164] Similarly, a longitudinal study of German high school students found significant pathways from media violence usage at Time 1 to higher physical aggression and lower empathy at Time 2 [13]. Whether due to media use or not, a lack of empathy has been noted as one of the best predictors of aggression against girls and women [165], and some studies note the effects of exposure to pornography on men's "sexual callousness" and their beliefs that women enjoy being victims of sexual aggression $[41,166]$.

Research on the association between actual sexual offending and reduced empathy is more ambiguous [167]; however, it has been suggested that high levels of empathy might reduce the expression of sexually aggressive behavior in males who might otherwise be at high-risk for perpetration [168]. Relatedly, low empathy has been linked with aggressive and antisocial behavior. Meta-analyses have shown that violent offenders have less cognitive empathy (the ability to understand another's emotions and feelings) and affective empathy (the ability to share another's emotional state) than non-offenders [169]. Relatedly, studies have found that sexually coercive men score higher on empathic deficits measures [170], and juvenile delinquents convicted of sexual offences scored significantly lower on empathic concern than non-sexual offending delinquent youth [171]. Thus, although it is likely that IP might have a disproportionately negative effect on the behavior of those already lacking in empathy (to our knowledge, this is yet to be tested empirically), the effects of degrading and aggressive IP on all viewers is worthy of further consideration. In the same way that humanitarian organizations struggle with growing "public numbness" to even the most starkly depicted human suffering [172], frequent viewers of aggressive and degrading IP may become inured to the sexualized aggression depicted against women 
in IP. For some viewers, this indifference may also make it more likely that they enact such behaviors offline.

\subsubsection{IP and Moral Disengagement}

Reduced empathy and desensitization to the suffering of others are significant because both of these factors have been found to encourage moral disengagement from victims depicted in media content [9,173-175]. Brockmyer [176] proposes that this process is likely gradual and unconscious, occurring as a result of repeated presentations of violence as necessary, justified, and enjoyable. Ongoing exposure to IP may also desensitize viewers to the depicted conduct (for a detailed explanation of the neuroscience underpinning this process see Carnegy et al. [177]), in much the same way that is revealed in brain imaging studies of accumulated desensitization to media violence (e.g., see Gentile et al. [178]). Repeated exposure to pornography has been found to desensitize young people to the material viewed and to lead to distorted views of what are "acceptable" behaviors in relationships [179]. As Scarpati and Pina [180] propose in their review examining the cultural and moral dimensions of sexual aggression, "... when individuals are nurtured in a culture which provides them with the justifications they need to blame the victim, moral disengagement mechanisms may not only be easily accessible and applicable, but may also encourage the occurrence of sexual violence by cognitively distorting the moral repercussions around it" (p. 119). Relatedly, hostile sexist attitudes toward women have been found to be the most powerful predictor of both IPV myths and moral disengagement [181].

The psychological mechanism by which moral disengagement affects actual behavior is well established. Through socialization processes, individuals adopt standards of right and wrong which guide their conduct. Once these moral standards are internalized, the individual can use them to judge the morality of their own conduct and to self-regulate accordingly [182]. Typically, actions that bring satisfaction and a sense of self-worth are preferred, and behaviors that violate moral standards are avoided, as they elicit self-condemnation. However, moral standards do not function as perpetual internal regulators of conduct, and self-regulatory mechanisms only operate if they are activated. Bandura [183] notes that "self-sanctions can be disengaged by reconstruing conduct, obscuring causal agency, disregarding or misrepresenting injurious consequences, and blaming and devaluating the victims" (p. 28). To illustrate, in relation to sexual harassment, euphemistic labelling facilitates the relabeling of harassing behaviors as "flirting", "banter", or "joking", thereby veiling the harms associated with this conduct [184]. In much the same way, repeated presentations of what appears to be culturally acceptable sexualized violence in IP, coupled with the depiction of sexual enjoyment by both the perpetrator and receiver of this violence, could similarly enable viewers to morally disengage from this conduct by relabeling acts of aggression and degradation as acceptable, normal sexual behavior.

In his most recent work, Bandura [121] argued that there are four loci at which moral self-censure can be selectively disengaged from harmful conduct: behavioral, agency, effects, and the victim. The behavioral locus refers to harmful behavior being transmuted into supposedly good behavior via rationalization. Overall, three mechanisms of justification operate at the behavioral locus: moral, social, and economic justifications are used to endorse injurious practices, and viewing harmful activities as serving worthy ends, eliminates any self-censure for engaging in the practice. Thus, viewers of IP might assure themselves that IP consumption is normative, harmless, and inevitable, regardless of their personal viewing choice, perhaps even justifying it as serving an economic benefit for the actors who earn an income performing in IP. In a similar vein, a recent study found that two dimensions of ambivalent sexism were particularly predictive of rape myth beliefs and victim blaming: hostility toward women and benevolence toward men [185].

The agency locus refers to the displacement or obfuscation of blame as to who is responsible for harmful acts [121]. Two mechanisms enable this locus: the displacement of responsibility and the diffusion of responsibility. Displacement refers to the minimization of one's role in harm or the transposition of blame onto others, such as when viewers 
blame the female actors for choosing to be a part of IP and accordingly dismiss them as deserving whatever treatment they receive. Displacement also allows people to view their actions as arising from the social pressures or dictates of others, rather than as something for which they are personally responsible [186]. In this way, violent and degrading IP can be viewed simply as a rational response to economic demand and the prevailing sexual milieu, for which an individual viewer cannot be held accountable. Similarly, diffusion of responsibility refers to widespread sharing of blame, such as when viewers of IP mitigate the harms depicted in IP by reassuring themselves that millions of others are watching the same material, making their participation inconsequential.

The effects locus refers to attempted explanations for effects, the key contrivances being disregard, distortion, and denial of harmful effects. If an individual is able to keep the detrimental effects of IP out of their contemplation, there is little impetus for self-censure to be initiated. As Bandura [187] has previously noted, "It is easier to harm others when their suffering is not visible and when injurious actions are physically and temporally remote from their effects" (p. 7). Thus, by objectifying female porn actors and disregarding them as nothing more than sexual entities [82], viewers can deny any similarity these women may have to their partners, mothers, sisters, or friends, negating their humanity and the harm caused to them by the depicted behaviors.

Finally, the victim locus refers to attempts to displace blame onto the victim themselves. The two main mechanisms that facilitate this are dehumanization of the victim and attribution of blame to the victim $[121,187]$. In the case of violent mainstream IP, "the ability of viewers to experience pleasure in extreme online pornography is predicated on the denial of harm of those viewed and the fantasy that women 'want it' or make economically rational, and thus voluntary, choices to take part" [18]. This displacement of blame, coupled with dehumanization, allows viewers to discount or disregard any of the physical and psychological consequences of the depicted activities on the female actors involved, despite studies suggesting these are numerous [81,188].

\section{Conclusions}

Online technology has both amplified and normalized the capacity to engage in or view a range of violent acts whereby the pain, suffering, and humiliation of others is offered up for instantaneous gratification. The processes by which mass media depictions of violence impact the viewer are well-documented, but the impacts of IP in which women are hurt, degraded and/or abused is understudied. This theoretical review has explored these impacts, the underlying psychological processes, and the wider social impacts via two proposed hypotheses. Firstly, it has shown that these impacts are facilitated to some extent, by the positioning of IP as a zone of cultural exception where sexual acts can be viewed, shared, and appraised, with the understanding that any act, regardless of how degrading or violent it is, is not just permitted, but rewarded. Given the ubiquity of IP, it is not unreasonable to suggest that online depictions of violence, coercion and degradation also have the potential to seep into real-life attitudes, beliefs, and behaviors.

Secondly, this review has shown how the objectification and dehumanization of women in IP can lead to real world violence both through the acquisition of violent and coercive sexual scripts and by creating cultural expectations that women are fungible objects that may be abused and violated with impunity $[70,146,150]$. Dehumanization and objectification in IP are also mutually reinforcing, in that, together, they permit the displacement of responsibility for the harms being perpetrated, whilst allowing viewers to eschew any of the cognitive discomfort or guilt they might experience whilst viewing this behavior [121]. In terms of psychological mechanisms, there is no evidence that media depictions of sexualized violence are somehow psychologically quarantined in a way that reduces or negates their influence on the feelings, thoughts, or actions of those who regularly watch such material.

The effects of IP on sexual violence and IPV may not be large, but it is worth noting that the statistically small effects of media violence on aggressive behavior can have important 
societal consequences, since (a) a large portion of the population has exposure to media violence at any given time, (b) effects seem to accumulate with repeated exposure, and (c) this risk factor can augment other risk factors to increase overall risk [111]. Points (a) and (c) seem to also be relevant to understanding the potential for IP to impact sexual aggression, but more longitudinal research is needed concerning cumulative effects. Whilst violence depicted in much mainstream heterosexual IP is just one of the many factors that may contribute to offline aggression and violence against women, it is a pervasive cultural edifice that embodies disrespect to and aggression against women. In a context in which IP is replete with sexual scripts related to verbal and physical abuse, the malleability of sexual consent and the depicted desire by women to be subjugated and hurt by men $[6,90,112,189]$, the time seems right for researchers, clinicians, and policy makers to begin a significant discourse on how best to address this important cultural and social issue.

\section{Limitations and Future Research}

In this review we have endeavoured to synthesize existing theories, related concepts, and empirical research to propose a theoretical framework for understanding the potential link between mainstream violent and aggressive IP, and aggression and violence against women. This review is not an exhaustive systematic review of all available IP research. Nevertheless, the approach taken with this theoretical review is still germane given the complex, multi-disciplinary, and contested nature of IP research. Particularly in the field of human sciences, reviews of theory such as this one may assist attempts to navigate diverse literature and potentially lead to insights into how factors relate to one another in ways that can judiciously inform policy [190]. From here, further work is needed to empirically validate the proposed relationships. Specifically, research is needed to determine the specific pathways from IP consumption to actual behavior. This would assist in the clarification of some current findings, including longitudinal research which has shown that early and more frequent exposure to pornography are both associated with the initiation of sexual behaviors at a younger age among adolescents [191,192], and cross sectional studies showing that young people use IP as a form of sexual education, and incorporate pornography-inspired practices into their real-life sexual experiences, even when they find many of these practices distasteful [2,193]. Similarly, longitudinal studies will be necessary to test the directionality of the hypothesized link between IP consumption and aggressive and violent conduct towards women, and these studies would need to clearly define sexually aggressive, coercive, and violent conduct, and consider any potential covariates. Future research examining the nature of same sex IP content and its interpretation by gender and sexuality diverse individuals would also be extremely valuable. It is hoped that this initial theoretical review serves to generate both robust discourse and empirical examination around these issues, with positive public health outcomes being the ultimate objective.

Author Contributions: Conceptualization, S.B. and W.A.W.; methodology, S.B. and W.A.W.; validation, S.B., W.A.W., K.B. and N.S.; formal analysis, S.B.; data curation, S.B.; writing-original draft preparation, S.B.; writing-review and editing, S.B., W.A.W., K.B. and N.S.; visualization, S.B., W.A.W., K.B. and N.S. All authors have read and agreed to the published version of the manuscript.

Funding: This research received no external funding.

Institutional Review Board Statement: Not applicable.

Informed Consent Statement: Not applicable.

Data Availability Statement: Not applicable.

Conflicts of Interest: The authors declare no conflict of interest. 


\section{References}

1. Carroll, J.S.; Padilla-Walker, L.M.; Nelson, L.J.; Olson, C.D.; Barry, C.M.; Madsen, S.D. Generation XXX. J. Adolesc. Res. 2008, 23, 6-30. [CrossRef]

2. Svedin, C.G.; Åkerman, I.; Priebe, G. Frequent users of pornography. A population based epidemiological study of Swedish male adolescents. J. Adolesc. 2011, 34, 779-788. [CrossRef] [PubMed]

3. Lim, M.S.; Agius, P.; Carrotte, E.R.; Vella, A.M.; Hellard, M.E. Young Australians' use of pornography and associations with sexual risk behaviours. Aust. N. Z. J. Public Health 2017, 41, 438-443. [CrossRef] [PubMed]

4. Vandello, J.A.; Cohen, D. Culture, Gender, and Men's Intimate Partner Violence. Soc. Pers. Psychol. Compass 2008, 2, 652-667. [CrossRef]

5. $\quad$ Bridges, A.J.; Wosnitzer, R.; Scharrer, E.; Sun, C.; Liberman, R. Aggression and Sexual Behavior in Best-Selling Pornography Videos: A Content Analysis Update. Violence Against Women 2010, 16, 1065-1085. [CrossRef]

6. Angel, J.; Bridges, A.; Chomsky, N.; Dines, G.; Greene, E.; Jensen, R.; Kaempfer, A.; Levy, A.; Lewis, S.K.; McDonough, T.; et al. The Price of Pleasure: Pornography, Sexuality \& Relationships; Kanopy Streaming: San Francisco, CA, USA, 2014.

7. Sun, C.; Ezzell, M.B.; Kendall, O. Naked Aggression: The Meaning and Practice of Ejaculation on a Woman's Face. Violence Against Women 2017, 23, 1710-1729. [CrossRef]

8. Whisnant, R. Pornography, Humiliation, and Consent. Sex. Media Soc. 2016, 2, 2374623816662876. [CrossRef]

9. Anderson, C.A.; Shibuya, A.; Ihori, N.; Swing, E.L.; Bushman, B.J.; Sakamoto, A.; Rothstein, H.R.; Saleem, M. Violent video game effects on aggression, empathy, and prosocial behavior in Eastern and Western countries: A meta-analytic review. Psychol. Bull. 2010, 136, 151-173. [CrossRef]

10. Bushman, B.J.; Huesmann, L.R. Short-term and Long-term Effects of Violent Media on Aggression in Children and Adults. Arch. Pediatr. Adolesc. Med. 2006, 160, 348-352. [CrossRef]

11. Greitemeyer, T.; Mügge, D.O. Video Games Do Affect Social Outcomes. Pers. Soc. Psychol. Bull. 2014, 40, 578-589. [CrossRef]

12. Paik, H.J.; Comstock, G. The effects of television violence on antisocial behaviour: A meta-analysis. Commun. Res. 1994, 21, 516-546. [CrossRef]

13. Krahé, B.; Möller, I. Longitudinal effects of media violence on aggression and empathy among German adolescents. J. Appl. Dev. Psychol. 2010, 31, 401-409. [CrossRef]

14. Möller, I.; Krahé, B. Exposure to violent video games and aggression in German adolescents: A longitudinal analysis. Aggress. Behav. 2009, 35, 75-89. [CrossRef]

15. Smith, S.; Dines, G. Porn and the misogyny emergency. Overland 2012, 207, 18-23.

16. Wright, P.J.; Tokunaga, R.S.; Kraus, A. A Meta-Analysis of Pornography Consumption and Actual Acts of Sexual Aggression in General Population Studies. J. Commun. 2016, 66, 183-205. [CrossRef]

17. Gossett, J.L.; Byrne, S. "Click here” a content analysis of Internet rape sites.(Abstract). Gend. Soc. 2002, 16, 689. [CrossRef]

18. Atkinson, R.; Rodgers, T. Pleasure Zones and Murder Boxes: Online Pornography and Violent Video Games as Cultural Zones of Exception. Br. J. Criminol. 2016, 56, 1291-1307. [CrossRef]

19. Langton, R. Sexual Solipsism: Philosophical Essays on Pornography and Objectification; Oxford University Press: Oxford, UK, 2009.

20. WHO. Global and Regional Estimates of Violence against Women: Prevalence and Health Effects of Intimate Partner Violence and Non-Partner Sexual Violence; World Health Organisation: Geneva, Switzerland, 2013.

21. AIHW. Family, Domestic and Sexual Violence in Australia; Australian Institute of Health and Welfare: Canberra, Australia, 2018.

22. Petrosky, E.; Blair, J.M.; Betz, C.J.; Fowler, K.A.; Jack, S.P.; Lyons, B.H. Racial and Ethnic Differences in Homicides of Adult Women and the Role of Intimate Partner Violence-United States, 2003-2014. Morb. Mortal. Wkly. Rep. 2017, 66, 741. [CrossRef]

23. Bryant, W.; Bricknell, S. Homicide in Australia 2012-13 to 2013-14: National homicide monitoring program report. In National Homicide Monitoring Program Report: Statistical Reports No. 2; Australian Institute of Criminology: Canberra, Australia, 2017.

24. FRA; European Union Agency for Fundamental Rights. Crime, safety and victims' rights. In Fundamental Rights Survey; Publications Office of the European Union: Luxembourg, 2021.

25. Kann, L.; McManus, T.; Harris, W.A.; Shanklin, S.L.; Flint, K.H.; Queen, B.; Lowry, R.; Chyen, D.; Whittle, L.; Thornton, J.; et al. Youth Risk Behavior Surveillance United States. MMWR Surveill. Summ. 2018, 67, 1. [CrossRef]

26. De Visser, R.O.; Badcock, P.; Rissel, C.; Richters, J.; Smith, A.M.A.; Grulich, A.E.; Simpson, J.M. Experiences of sexual coercion in a representative sample of adults: The Second Australian Study of Health and Relationships. Sex. Health 2014, 11, 472-480 [CrossRef]

27. Price, J.; Patterson, R.; Regnerus, M.; Walley, J. How Much More XXX is Generation X Consuming? Evidence of Changing Attitudes and Behaviors Related to Pornography Since 1973. J. Sex Res. 2016, 53, 1-9. [CrossRef]

28. Rissel, C.; Richters, J.; de Visser, R.; McKee, A.; Yeung, A.; Caruana, T. A Profile of Pornography Users in Australia: Findings From the Second Australian Study of Health and Relationships. J. Sex Res. 2017, 54, 227-240. [CrossRef]

29. Pornhub. The 2019 Year in Review. 2019. Available online: https://www.pornhub.com/insights/2019-year-in-review\#countries (accessed on 12 January 2020).

30. Martellozzo, E.; Monaghan, A.; Adler, J.R.; Davidson, J.; Leyva, R.; Horvath, M.A.H. "I Wasn't Sure It Was Normal to Watch It ... " A Quantitative and Qualitative Examination of the Impact of Online Pornography on the Values, Attitudes, Beliefs and Behaviours of Children and Young People; Middlesex University: London, UK, 2016. 
31. Maltz, W.; Maltz, L. The Porn Trap: The Essential Guide to Overcoming Problems Caused by Pornography; HarperCollins: New York, NY, USA, 2008.

32. Watson, M.A.; Smith, R.D. Positive Porn: Educational, Medical, and Clinical Uses. Am. J. Sex. Educ. 2012, 7, 122-145. [CrossRef]

33. Hare, K.A.; Gahagan, J.; Jackson, L.; Steenbeek, A. Revisualising 'porn': How young adults' consumption of sexually explicit Internet movies can inform approaches to Canadian sexual health promotion. Cult. Health Sex. 2015, 17, 269-283. [CrossRef]

34. Træen, B.; Daneback, K. The use of pornography and sexual behaviour among Norwegian men and women of differing sexual orientation. Sexologies 2013, 22, e41-e48. [CrossRef]

35. Hald, G.M.; Malamuth, N.M. Self-Perceived Effects of Pornography Consumption. Arch. Sex. Behav. 2008, 37, 614-625. [CrossRef]

36. Dines, G. Pornland: How Porn Has Hijacked Our Sexuality; Beacon Press: Boston, MA, USA, 2010.

37. Wright, P.J.; Sun, C.; Steffen, N.J.; Tokunaga, R.S. Pornography, Alcohol, and Male Sexual Dominance. Commun. Monogr. 2015, 82, 252-270. [CrossRef]

38. Short, M.B.; Black, L.; Smith, A.H.; Wetterneck, C.T.; Wells, D.E. A Review of Internet Pornography Use Research: Methodology and Content from the Past 10 Years. Cyberpsychol. Behav. Soc. Netw. 2012, 15, 13-23. [CrossRef]

39. Fisher, W.A.; Barak, A. Internet pornography: A social psychological perspective on internet sexuality. J. Sex Res. 2001, 38, 312-323. [CrossRef]

40. Crabbe, M.; Corlett, D. Eroticising inequality: Technology, pornography and young people. Redress 2011, 20, 11-15.

41. Check, J.V.P.; Guloien, T.H. The effects of repeated exposure to sexually violent pornography, nonviolent dehumanizing pornography, and erotica. In Pornography: Research Advances and Policy Considerations; Zillmann, D., Bryant, J., Eds.; Erlbaum: Hillsdale, NJ, USA, 1989.

42. Boyland, E.; Halford, J.C. Television advertising and branding. Effects on eating behaviour and food preferences in children. Appetite 2013, 62, 236-241. [CrossRef]

43. Smith, L.A.; Foxcroft, D.R. The effect of alcohol advertising, marketing and portrayal on drinking behaviour in young people: Systematic review of prospective cohort studies. BMC Public Health 2009, 9, 51. [CrossRef] [PubMed]

44. Kirkorian, H.L.; Anderson, D.R. Learning from educational media. In The Handbook of Children, Media, and Development; Calvert, S.L., Wilson, B.J., Eds.; Wiley-Blackwell: Chichester, UK, 2008; pp. 188-213.

45. Ferguson, C.J. Media Violence Effects and Violent Crime: Good Science or Moral Panic? In Violent Crime: Clinical and Social Implications; Ferguson, C.J., Ed.; Sage Publications: Thousand Oaks, CA, USA, 2010.

46. Foubert, J.D. The Public Health Harms of Pornography: The Brain, Erectile Dysfunction, and Sexual Violence. Dign. J. Sex. Exploit. Violence 2017, 2, 6. [CrossRef]

47. Krahé, B.; Berkowitz, L.; Moller, I.; Warburton, W.; Brockmyer, J.H.; Bushman, B.J.; Coyne, S.M.; Dill, K.E.; Donnerstein, E.; Gentile, D.; et al. Report of the Media Violence Commission. Aggress. Behav. 2012, 38, 335-341. [CrossRef]

48. Huesmann, L.R.; Moise-Titus, J.; Podolski, C.-L.; Eron, L.D. Longitudinal relations between children's exposure to TV violence and their aggressive and violent behavior in young adulthood: 1977-1992. Dev. Psychol. 2003, 39, 201-221. [CrossRef]

49. Rodenhizer, K.A.E.; Edwards, K.M. The Impacts of Sexual Media Exposure on Adolescent and Emerging Adults' Dating and Sexual Violence Attitudes and Behaviors: A Critical Review of the Literature. Trauma Violence Abus. 2019, 20, 439-452. [CrossRef]

50. Warburton, W.A.; Roberts, D.F.; Christensen, P.G. The Effects of Violent and Antisocial Music on Children and Adolescents; California Praeger: Santa Barbara, CA, USA, 2014.

51. Przybylski, A.K.; Weinstein, N. Violent video game engagement is not associated with adolescents' aggressive behaviour: Evidence from a registered report. R. Soc. Open Sci. 2019, 6, 171474. [CrossRef]

52. McCarthy, R.J.; Coley, S.L.; Wagner, M.F.; Zengel, B.; Basham, A. Does playing video games with violent content temporarily increase aggressive inclinations? A pre-registered experimental study. J. Exp. Soc. Psychol. 2016, 67, 13-19. [CrossRef]

53. Savage, J.; Yancey, C. The Effects of Media Violence Exposure On Criminal Aggression. Crim. Justice Behav. 2008, 35, 772-791. [CrossRef]

54. Furuya-Kanamori, L.; Doi, S.A.R. Angry Birds, Angry Children, and Angry Meta-Analysts. Perspect. Psychol. Sci. 2016, 11, 408-414. [CrossRef]

55. Ferguson, C.J.; Kilburn, J. The Public Health Risks of Media Violence: A Meta-Analytic Review. J. Pediatr. 2009, 154, 759-763. [CrossRef]

56. Ferguson, C.J. Evidence for publication bias in video game violence effects literature: A meta-analytic review. Aggress. Violent Behav. 2007, 12, 470-482. [CrossRef]

57. Ferguson, C.J. The Good, The Bad and the Ugly: A Meta-analytic Review of Positive and Negative Effects of Violent Video Games. Psychiatr. Q. 2007, 78, 309-316. [CrossRef]

58. Elson, M.; Ferguson, C.J. Twenty-Five Years of Research on Violence in Digital Games and Aggression. Eur. Psychol. 2014, 19, 33-46. [CrossRef]

59. Ferguson, C.J.; Savage, J. Have recent studies addressed methodological issues raised by five decades of television violence research? A critical review. Aggress. Violent Behav. 2012, 17, 129-139. [CrossRef]

60. Hilgard, J.; Engelhardt, C.R.; Rouder, J.N. Overstated evidence for short-term effects of violent games on affect and behavior: A reanalysis of Anderson et al. (2010). Psychol. Bull. 2017, 143, 757-774. [CrossRef]

61. Sherry, J.L. Mass media effects research advances through meta-analysis. In Mass Media Effects Research: Advances through Meta-Analysis; Preiss, R.W., Gayle, B.M., Burrell, N., Allen, M., Eds.; Ringgold Inc: Portland, OR, USA, 2007. 
62. Bushman, B.J.; Huesmann, L.R. Twenty-Five Years of Research on Violence in Digital Games and Aggression Revisited. Eur. Psychol. 2014, 19, 47-55. [CrossRef]

63. Krahé, B. Restoring the Spirit of Fair Play in the Debate About Violent Video Games. Eur. Psychol. 2014, 19, 56-59. [CrossRef]

64. Warburton, W. Apples, Oranges, and the Burden of Proof-Putting Media Violence Findings Into Context. Eur. Psychol. 2014, 19, 60-67. [CrossRef]

65. Anderson, C.A.; Bushman, B.J.; Donnerstein, E.; Hummer, T.A.; Warburton, W. SPSSI Research Summary on Media Violence. Anal. Soc. Issues Public Policy 2015, 15, 4-19. [CrossRef]

66. Gentile, D.A.; Bushman, B.J. Reassessing media violence effects using a risk and resilience approach to understanding aggression. Psychol. Popul. Media Cult. 2012, 1, 138-151. [CrossRef]

67. Prot, S.; Gentile, D.A. Applying risk and resilience models to predicting the effects of media violence on development. Adv. Child Dev. Behav. 2014, 46, 215. [PubMed]

68. Sun, C.; Bridges, A.; Wosnitzer, R.; Scharrer, E.; Liberman, R. A Comparison of Male and Female Directors in Popular Pornography: What Happens when Women are at the Helm? Psychol. Women Q. 2008, 32, 312-325. [CrossRef]

69. Gorman, S.; Monk-Turner, E.; Fish, J.N. Free Adult Internet Web Sites: How Prevalent Are Degrading Acts? Gend. Issues 2010, 27, 131-145. [CrossRef]

70. Fritz, N.; Paul, B. From Orgasms to Spanking: A Content Analysis of the Agentic and Objectifying Sexual Scripts in Feminist, for Women, and Mainstream Pornography. Sex Roles 2017, 77, 639-652. [CrossRef]

71. Shor, E.; Seida, K. "Harder and Harder"? Is Mainstream Pornography Becoming Increasingly Violent and Do Viewers Prefer Violent Content? J. Sex Res. 2018, 56, 16-28. [CrossRef]

72. McKee, A. The objectification of women in mainstream pornographic videos in Australia. J. Sex Res. 2005, 42, 277-290. [CrossRef]

73. McKee, A. The Aesthetics of Pornography: The Insights of Consumers. Continuum 2006, 20, 523-539. [CrossRef]

74. Weitzer, R. Pornography's effects: The need for solid evidence: A review essay of Everyday Pornography, edited by Karen Boyle and Pornland: How porn has hijacked our sexuality, by Gail Dines. Violence Against Women 2011, 17, 666-675. [CrossRef]

75. McKee, A. Methodological Issues in Defining Aggression for Content Analyses of Sexually Explicit Material. Off. Publ. Int. Acad. Sex Res. 2015, 44, 81-87. [CrossRef]

76. Peter, J.; Valkenburg, P.M. Adolescents' Exposure to Sexually Explicit Internet Material and Notions of Women as Sex Objects: Assessing Causality and Underlying Processes. J. Commun. 2009, 59, 407-433. [CrossRef]

77. Baron, R.A.; Richardson, D.R. Human Aggression, 2nd ed.; Plenum Press: New York, NY, USA, 1994.

78. Luzwick, A. Human Trafficking and Pornography: Using the Trafficking Victims Protection Act to prosecute trafficking for the production of Internet pornography. Northwestern Univ. Law Rev. 2017, 112, 355-375. [CrossRef]

79. MacKinnon, C.A. Pornography as trafficking. Mich. J. Int. Law 2005, 26, 993-1012.

80. APA. Report of the Task Force on Trafficking of Women and Girls; American Psychological Association: Washington, DC, USA, 2014.

81. Grudzen, C.R.; Ryan, G.; Margold, W.; Torres, J.; Gelberg, L. Pathways to Health Risk Exposure in Adult Film Performers. J. Hered. 2009, 86, 67-78. [CrossRef]

82. Seabrook, R.C.; Ward, L.M.; Giaccardi, S. Less than human? Media use, objectification of women, and men's acceptance of sexual aggression. Psychol. Violence 2019, 9, 536-545. [CrossRef]

83. Taylor, K.; Jackson, S. 'I want that power back': Discourses of masculinity within an online pornography abstinence forum. Sexualities 2018, 21, 621-639. [CrossRef]

84. Deem, G.; Reboot Nation. Simple Machines. 2019. Available online: http://www.rebootnation.org (accessed on 11 December 2018).

85. Foubert, J.; Brosi, M.W.; Bannon, R.S. Pornography Viewing among Fraternity Men: Effects on Bystander Intervention, Rape Myth Acceptance and Behavioral Intent to Commit Sexual Assault. Sex. Addict. Compulsivity 2011, 18, 212-231. [CrossRef]

86. DeKeseredy, W.S. Critical Criminological Understandings of Adult Pornography and Woman Abuse: New Progressive Directions in Research and Theory. Int. J. Crime Justice Soc. Democr. 2015, 4, 4-21. [CrossRef]

87. Papadopoulos, L. Sexualisation of Young People Review; UK Home Office: London, UK, 2010.

88. Owens, E.W.; Behun, R.J.; Manning, J.C.; Reid, R.C. The Impact of Internet Pornography on Adolescents: A Review of the Research. Sex. Addict. Compulsivity 2012, 19, 99-122. [CrossRef]

89. Flood, M. The harms of pornography exposure among children and young people. Child Abus. Rev. 2009, 18, 384-400. [CrossRef]

90. Stanley, N.; Barter, C.; Wood, M.; Aghtaie, N.; Larkins, C.; Lanau, A.; Överlien, C. Pornography, Sexual Coercion and Abuse and Sexting in Young People's Intimate Relationships: A European Study. J. Interpers. Violence 2018, 33, 2919-2944. [CrossRef] [PubMed]

91. Hald, G.M.; Malamuth, N.M.; Yuen, C. Pornography and attitudes supporting violence against women: Revisiting the relationship in nonexperimental studies. Aggress. Behav. 2010, 36, 14-20. [CrossRef] [PubMed]

92. Shope, J.H. When Words Are Not Enough. Violence Against Women 2004, 10, 56-72. [CrossRef]

93. Malamuth, N.M.; Addison, T.; Koss, M.P. Pornography and sexual aggression: Are there reliable effects and can we understand them? Annu. Rev. Sex Res. 2000, 11, 26.

94. Bridges, A.J. Pornography and Sexual Assault. In Handbook of Sexual Assault and Sexual Assault Prevention; O'Donohue, W., Schewe, P., Eds.; Springer: Cham, Switzerland, 2019. 
95. Kohut, T.; Baer, J.L.; Watts, B. Is PornographyReallyabout "Making Hate to Women"? Pornography Users Hold More Gender Egalitarian Attitudes Than Nonusers in a Representative American Sample. J. Sex Res. 2016, 53, 1-11. [CrossRef]

96. Ferguson, C.J.; Hartley, R.D. The pleasure is momentary ... the expense damnable?: The influence of pornography on rape and sexual assault. Aggress. Violent Behav. 2009, 14, 323-329. [CrossRef]

97. Bauserman, R. Sexual Aggression and Pornography: A Review of Correlational Research. Basic Appl. Soc. Psychol. 1996, 18, 405-427. [CrossRef]

98. Watson, L. A Reply to Weitzer. Violence Against Women 2012, 18, 502-505. [CrossRef]

99. Wright, P.J. Overcontrol in Pornography Research: Let it Go, Let it Go . . . Arch. Sex. Behav. 2021, 50, 387-392. [CrossRef]

100. Tydén, T.; Rogala, C. Sexual behaviour among young men in Sweden and the impact of pornography. Int. J. STD AIDS 2004, 15, 590-593. [CrossRef]

101. Rogala, C.; Tydén, T. Does pornography influence young women's sexual behavior? Women's Health Issues 2003, 13, 39-43. [CrossRef]

102. Sommers, E.K.; Check, J.V.P. An Empirical Investigation of the Role of Pornography in the Verbal and Physical Abuse of Women. Violence Vict. 1987, 2, 189-209. [CrossRef]

103. Russell, D. Making Violence Sexy: Feminist Views on Pornography; New York Teachers College Press: New York, NY, USA, 1993.

104. Moreau, C.; Boucher, S.; Hébert, M.; Lemelin, J. Capturing Sexual Violence Experiences Among Battered Women Using the Revised Sexual Experiences Survey and the Revised Conflict Tactics Scales. Off. Publ. Int. Acad. Sex Res. 2015, 44, $223-231$. [CrossRef]

105. Bergen, R.K.; Bogle, K.A. Exploring the Connection Between Pornography and Sexual Violence. Violence Vict. 2000, 15, $227-234$. [CrossRef]

106. Bandura, A. Social Cognitive theory of mass communication. In Media Effects: Advances in Theory and Research; Bryant, J., Zillmann, D., Eds.; Lawrence Erlbaum Associates: Mahwah, NJ, USA, 2002.

107. Gerbner, G.; Gross, L.; Morgan, M.; Signorielli, N. Growing up with television: The cultivation perspective. In Media Effects; Bryant, J., Zillmann, D., Eds.; Erlbaum: Hillsdale, NJ, USA, 1994; pp. 17-41.

108. Bandura, A. Social Foundations of Thought and Action: A Social Cognitive Theory; Prentice-Hall: Englewood Cliffs, NJ, USA, 1986.

109. Bandura, A. Social Learning Theory of Aggression. J. Commun. 1978, 28, 12-29. [CrossRef]

110. Sun, C.; Bridges; Johnson, J.A.; Ezzell, M.B. Pornography and the Male Sexual Script: An Analysis of Consumption and Sexual Relations. Arch. Sex. Behav. 2016, 45, 983-994. [CrossRef]

111. Anderson, C.A.; Berkowitz, L.; Donnerstein, E.; Huesmann, L.R.; Johnson, J.D.; Linz, D.; Malamuth, N.M.; Wartella, E. The Influence of Media Violence on Youth. Psychol. Sci. Public Interes. 2003, 4, 81-110. [CrossRef]

112. Paul, P. From pornography to porno to porn: How porn became the norm. In The Social Costs of Pornography; Stoner, J.R., Jr., Hughes, D.M., Eds.; Witherspoon Institute: New Jersey, NJ, USA, 2010.

113. Zillmann, D. Influence of unrestrained access to erotica on adolescents' and young adults' dispositions toward sexuality. J. Adolesc. Health 2000, 27, 41-44. [CrossRef]

114. Mullin, C.R.; Linz, D. Desensitization and resensitization to violence against women: Effects of exposure to sexually violent films on judgments of domestic violence victims. J. Pers. Soc. Psychol. 1995, 69, 449-459. [CrossRef]

115. Weisz, M.G.; Earls, C.M. The Effects of Exposure to Filmed Sexual Violence on Attitudes Toward Rape. J. Interpers. Violence 1995, 10, 71-84. [CrossRef]

116. Wright, P.J. Mass Media Effects on Youth Sexual Behavior Assessing the Claim for Causality. Ann. Int. Commun. Assoc. 2011, 35, 343-385. [CrossRef]

117. Wright, P.J.; Funk, M. Pornography Consumption and Opposition to Affirmative Action for Women. Psychol. Women Q. 2014, 38, 208-221. [CrossRef]

118. Allen, M.; D'Alessio, D.; Brezgel, K. A Meta-Analysis Summarizing the Effects of Pornography II Aggression After Exposure. Hum. Commun. Res. 1995, 22, 258-283. [CrossRef]

119. Hald, G.M.; Seaman, C.; Linz, D. Sexuality and pornography. In APA Handbook of Sexuality and Psychology, Vol. 2: Contextual Approaches; Tolman, D.L., Diamond, L.M., Bauermeister, J.A., George, W.H., Pfaus, J.G., Ward, L.M., Eds.; American Psychological Association: Washington, DC, USA, 2014; pp. 3-35.

120. Paul, B.; Salwen, M.B.; Dupagne, M. The Third-Person Effect: A Meta-Analysis of the Perceptual Hypothesis. Mass Commun. Soc. 2000, 3, 57-85. [CrossRef]

121. Bandura, A. Moral Disengagement: How People Do Harm and Live with Themselves; Worth Publishers: New York, NY, USA, 2016.

122. Wood, H. The internet and its role in the escalation of sexually compulsive behaviour. Psychoanal. Psychother. 2011, 25, 127-142. [CrossRef]

123. Wright, P.J.; Tokunaga, R.S. Men's Objectifying Media Consumption, Objectification of Women, and Attitudes Supportive of Violence Against Women. Arch. Sex. Behav. 2016, 45, 955-964. [CrossRef]

124. Freud, S. Civilization and Its Discontents; The Hogarth Press: London, UK, 1973.

125. Elias, N. The Civilizing Process: Sociogenetic and Psychogenetic Investigations; Goudsblom, J., Mennell, S., Dunning, E., Eds.; Blackwell Publishers: Hoboken, NJ, USA, 1939.

126. Cooper, A. Sexuality and the Internet: Surfing into the New Millennium. CyberPsychol. Behav. 1998, 1, 187-193. [CrossRef] 
127. Galatzer-Levy, R.M. Obscuring Desire: A Special Pattern of Male Adolescent Masturbation, Internet Pornography, and the Flight From Meaning. Psychoanal. Inq. 2012, 32, 480-495. [CrossRef]

128. Perloff, R.M. The third-person effect. In Media Effects: Advances in Theory and Research; Bryant, J., Zillmann, D., Eds.; Erlbaum: Mahwah, NJ, USA, 2002; pp. 489-506.

129. Chen, H.; Wu, Y.; Atkin, D.J. Third person effect and Internet pornography in China. Telemat. Inform. 2015, 32, 823-833. [CrossRef]

130. Lo, V.-H.; Wei, R. Third-Person Effect, Gender, and Pornography on the Internet. J. Broadcast. Electron. Media 2002, 46, 13-33. [CrossRef]

131. Gunther, A.C. Overrating the X-Rating: The Third-Person Perception and Support for Censorship of Pornography. J. Commun. 1995, 45, 27-38. [CrossRef]

132. Lee, B.; Tamborini, R. Third-Person Effect and Internet Pornography: The Influence of Collectivism and Internet Self-Efficacy. J. Commun. 2005, 55, 292-310. [CrossRef]

133. Rojas, H.; Shah, D.V.; Faber, R.J. For the Good of Others: Censorship and the Third-Person Effect. Int. J. Qual. Heal. Care 1996, 8, 163-186. [CrossRef]

134. Perloff, R.M. The Third Person Effect: A Critical Review and Synthesis. Media Psychol. 1999, 1, 353-378. [CrossRef]

135. Häggström-Nordin, E.; Hanson, U.; Tydén, T. Associations between pornography consumption and sexual practices among adolescents in Sweden. Int. J. STD AIDS 2005, 16, 102-107. [CrossRef]

136. Harkness, E.L.; Mullan, B.; Blaszczynski, A. Association between pornography use and sexual risk behaviors in adult consumers: A systematic review. Cyberpsychol. Behav. Soc. Netw. 2015, 18, 59-71. [CrossRef]

137. Fredrickson, B.L.; Roberts, T.-A. Objectification Theory: Toward Understanding Women's Lived Experiences and Mental Health Risks. Psychol. Women Q. 1997, 21, 173-206. [CrossRef]

138. Bernard, P.; Gervais, S.J.; Allen, J.; Campomizzi, S.; Klein, O. Integrating Sexual Objectification with Object Versus Person Recognition. Psychol. Sci. 2012, 23, 469-471. [CrossRef]

139. Gervais, S.J.; Vescio, T.K.; Allen, J. When are people interchangeable sexual objects? The effect of gender and body type on sexual fungibility. Br. J. Soc. Psychol. 2011, 51, 499-513. [CrossRef]

140. Heflick, N.; Goldenberg, J.L. Objectifying Sarah Palin: Evidence that objectification causes women to be perceived as less competent and less fully human. J. Exp. Soc. Psychol. 2009, 45, 598-601. [CrossRef]

141. Heflick, N.A.; Goldenberg, J.L.; Cooper, D.P.; Puvia, E. From women to objects: Appearance focus, target gender, and perceptions of warmth, morality and competence. J. Exp. Soc. Psychol. 2011, 47, 572-581. [CrossRef]

142. Gray, K.; Knobe, J.; Sheskin, M.; Bloom, P.; Barrett, L.F. More than a body: Mind perception and the nature of objectification. J. Pers. Soc. Psychol. 2011, 101, 1207-1220. [CrossRef] [PubMed]

143. Yin, R.K. Looking at upside-down faces. J. Exp. Psychol. 1969, 81, 141-145. [CrossRef]

144. Vance, K.; Sutter, M.; Perrin, P.B.; Heesacker, M. The Media's Sexual Objectification of Women, Rape Myth Acceptance, and Interpersonal Violence. J. Aggress. Maltreatment Trauma 2015, 24, 569-587. [CrossRef]

145. Loughnan, S.; Pina, A.; Vasquez, E.A.; Puvia, E. Sexual Objectification Increases Rape Victim Blame and Decreases Perceived Suffering. Psychol. Women Q. 2013, 37, 455-461. [CrossRef]

146. Klaassen, M.J.E.; Peter, J. Gender (In)equality in Internet Pornography: A Content Analysis of Popular Pornographic Internet Videos. J. Sex Res. 2015, 52, 721-735. [CrossRef]

147. Huesmann, L.R. The role of social information processing and cognitive schema in the acquisition and maintenance of habitual aggressive behavior. In Human Aggression: Theories, Research, and Implications for Social Policy; Geen, R.G., Donnerstein, E., Eds.; Academic Press: New York, NY, USA, 1998; pp. 73-109.

148. Aubrey, J.S.; Hopper, K.M.; Mbure, W.G. Check That Body! The Effects of Sexually Objectifying Music Videos on College Men's Sexual Beliefs. J. Broadcast. Electron. Media 2011, 55, 360-379. [CrossRef]

149. Rudman, L.A.; Mescher, K. Of Animals and Objects. Pers. Soc. Psychol. Bull. 2012, 38, 734-746. [CrossRef]

150. Gervais, S.J.; Eagan, S. Sexual objectification: The common thread connecting myriad forms of sexual violence against women. Am. J. Orthopsychiatry 2017, 87, 226-232. [CrossRef]

151. Flood, M.; Pease, B. Factors Influencing Attitudes to Violence Against Women. Trauma Violence Abus. 2009, 10, 125-142. [CrossRef]

152. Bernard, P.; Loughnan, S.; Marchal, C.; Godart, A.; Klein, O. The Exonerating Effect of Sexual Objectification: Sexual Objectification Decreases Rapist Blame in a Stranger Rape Context. Sex Roles 2015, 72, 499-508. [CrossRef]

153. Vasquez, E.A.; Ball, L.; Loughnan, S.; Pina, A. The object of my aggression: Sexual objectification increases physical aggression toward women. Aggress. Behav. 2017, 44, 5-17. [CrossRef] [PubMed]

154. Haslam, N.; Loughnan, S.; Reynolds, C.; Wilson, S. Dehumanization: A New Perspective. Soc. Pers. Psychol. Compass 2007, 1, 409-422. [CrossRef]

155. Bartky, S.L. Femininity and Domination: Studies in the Phenomenology of Oppression; Routledge: New York, NY, USA, 1990.

156. Nussbaum, M.C. Sex and Social Justice; Oxford University Press: New York, NY, USA, 1998.

157. Haslam, N. Dehumanization: An Integrative Review. Pers. Soc. Psychol. Rev. 2006, 10, 252-264. [CrossRef]

158. Moller, A.C.; Deci, E.L. Interpersonal control, dehumanization, and violence: A self-determination theory perspective. Group Process. Intergroup Relat. 2010, 13, 41-53. [CrossRef]

159. Konrath, S. The empathy paradox. In Handbook of Research on Technoself: Identity in a Technological Society; Luppicini, R., Ed.; Information Science Reference: Hershey, PA, USA, 2013; pp. 204-228. 
160. Gabbiadini, A.; Riva, P.; Andrighetto, L.; Volpato, C.; Bushman, B.J. Acting like a Tough Guy: Violent-Sexist Video Games, Identification with Game Characters, Masculine Beliefs, \& Empathy for Female Violence Victims. PLoS ONE 2016, 11, e0152121. [CrossRef]

161. Orwin, C. Distant Compassion. Natl. Interest 1996, 43, 42-49.

162. Bushman, B.J.; Anderson, C.A. Comfortably numb: Desensitizing effects of violent media on helping others. Psychol. Sci. 2009, 20, 273. [CrossRef]

163. Greitemeyer, T.; Osswald, S. Effects of prosocial video games on prosocial behavior. J. Pers. Soc. Psychol. 2010, 98, 211-221. [CrossRef]

164. Anderson, C.A.; Suzuki, K.; Swing, E.L.; Groves, C.L.; Gentile, D.; Prot, S.; Lam, C.P.; Sakamoto, A.; Horiuchi, Y.; Krahé, B.; et al. Media Violence and Other Aggression Risk Factors in Seven Nations. Pers. Soc. Psychol. Bull. 2017, 43, 986-998. [CrossRef]

165. Sanday, P.R. The Socio-Cultural Context of Rape: A Cross-Cultural Study. J. Soc. Issues 1981, 37, 5-27. [CrossRef]

166. Zillmann, D. Effects of prolonged consumption of pornography. In Pornography: Research Advances and Policy Considerations; Zillmann, D., Bryant, J., Eds.; Erlbaum: Hillsdale, NJ, USA, 1989; pp. 127-157.

167. Baly, A.; Butler, S. Empathy deficits and adolescent sexual offending: A systematic review of the evidence base. Aggress. Violent Behav. 2017, 36, 81-97. [CrossRef]

168. Malamuth, N.M.; Linz, D.; Heavey, C.L.; Barnes, G.; Acker, M. Using the confluence model of sexual aggression to predict men's conflict with women: A 10-year follow-up study. J. Personal. Soc. Psychol. 1995, 69, 353-369. [CrossRef]

169. van Langen, M.; Wissink, I.; van Vugt, E.; van der Stouwe, T.; Stams, G. The relation between empathy and offending: A meta-analysis. Aggress. Violent Behav. 2014, 19, 179-189. [CrossRef]

170. DeGue, S.; DiLillo, D. "You would if you loved me": Toward an improved conceptual and etiological understanding of nonphysical male sexual coercion. Aggress. Violent Behav. 2005, 10, 513-532. [CrossRef]

171. Lindsey, R.E.; Carlozzi, A.F.; Eells, G.T. Differences in the Dispositional Empathy of Juvenile Sex Offenders, Non-Sex-Offending Delinquent Juveniles, and Nondelinquent Juveniles. J. Interpers. Violence 2001, 16, 510-522. [CrossRef]

172. Dean, C.J. Empathy, Pornography, and Suffering. Differences 2003, 14, 88-124. [CrossRef]

173. Hartmann, T.; Krakowiak, K.M.; Tsay-Vogel, M. How Violent Video Games Communicate Violence: A Literature Review and Content Analysis of Moral Disengagement Factors. Commun. Monogr. 2014, 81, 310-332. [CrossRef]

174. Beck, V.S.; Boys, S.; Rose, C.; Beck, E. Violence Against Women in Video Games: A Prequel or Sequel to Rape Myth Acceptance? J. Interpers. Violence 2012, 27, 3016-3031. [CrossRef]

175. Fox, J.; Potocki, B. Lifetime Video Game Consumption, Interpersonal Aggression, Hostile Sexism, and Rape Myth Acceptance. J. Interpers. Violence 2016, 31, 1912-1931. [CrossRef]

176. Brockmyer, J.F. Playing Violent Video Games and Desensitization to Violence. Child Adolesc. Psychiatr. Clin. North Am. 2015, 24, 65-77. [CrossRef]

177. Carnagey, N.L.; Anderson, C.; Bartholow, B.D. Media Violence and Social Neuroscience. Curr. Dir. Psychol. Sci. 2007, 16, 178-182. [CrossRef]

178. Gentile, D.A.; Swing, E.L.; Anderson, C.A.; Rinker, D.; Thomas, K.M. Differential neural recruitment during violent video game play in violent- and nonviolent-game players. Psychol. Popul. Media Cult. 2016, 5, 39-51. [CrossRef]

179. Prescott, D.S.; Schuler, S.A. Pornography and Its Place in the Assessment and Treatment of Adolescents Who Have Sexually Abused; Neari Press: Holyoke, MA, USA, 2011.

180. Scarpati, A.S.; Pina, A. Cultural and moral dimensions of sexual aggression: The role of moral disengagement in men's likelihood to sexually aggress. Aggress. Violent Behav. 2017, 37, 115-121. [CrossRef]

181. Rollero, C.; De Piccoli, N. Myths about Intimate Partner Violence and Moral Disengagement: An Analysis of Sociocultural Dimensions Sustaining Violence against Women. Int. J. Environ. Res. Public Health 2020, 17, 8139. [CrossRef]

182. Bandura, A. Social Learning Theory; Prentice-Hall: Englewood Cliffs, NJ, USA, 1977.

183. Bandura, A. Selective Activation and Disengagement of Moral Control. J. Soc. Issues 1990, 46, 27-46. [CrossRef]

184. Page, T.E.; Pina, A. Moral disengagement and self-reported harassment proclivity in men: The mediating effects of moral judgment and emotions. J. Sex. Aggress. 2018, 24, 157-180. [CrossRef]

185. Rollero, C.; Tartaglia, S. The Effect of Sexism and Rape Myths on Victim Blame. Sex. Cult. 2019, 23, 209-219. [CrossRef]

186. Bandura, A.; Barbaranelli, C.; Caprara, G.V.; Pastorelli, C. Mechanisms of moral disengagement in the exercise of moral agency. J. Pers. Soc. Psychol. 1996, 71, 364-374. [CrossRef]

187. Bandura, A. Moral Disengagement in the Perpetration of Inhumanities. Pers. Soc. Psychol. Rev. 1999, 3, 193-209. [CrossRef]

188. Grudzen, C.R.; Elliott, M.N.; Kerndt, P.R.; Schuster, M.A.; Brook, R.H.; Gelberg, L. Condom Use and High-Risk Sexual Acts in Adult Films: A Comparison of Heterosexual and Homosexual Films. Am. J. Public Health 2009, 99, S152-S156. [CrossRef] [PubMed]

189. Peter, J.; Valkenburg, P.M. Processes Underlying the Effects of Adolescents' Use of Sexually Explicit Internet Material: The Role of Perceived Realism. Commun. Res. 2010, 37, 375-399. [CrossRef]

190. Campbell, M.; Egan, M.; Lorenc, T.; Bond, L.; Popham, F.; Fenton, C.; Benzeval, M. Considering methodological options for reviews of theory: Illustrated by a review of theories linking income and health. Syst. Rev. 2014, 3, 114. [CrossRef] [PubMed]

191. Brown, J.D.; L'Engle, K.L. X-rated: Sexual attitudes and behaviors associated with U.S. early adolescents' exposure to sexually explicit media. Commun. Res. 2009, 36, 129. [CrossRef] 
192. VandenBosch, L.; Eggermont, S. Sexually Explicit Websites and Sexual Initiation: Reciprocal Relationships and the Moderating Role of Pubertal Status. J. Res. Adolesc. 2012, 23, 621-634. [CrossRef]

193. Scarcelli, C.M. 'It is disgusting, but ... ': Adolescent girls' relationship to internet pornography as gender performance. Porn Stud. 2015, 2, 237-249. [CrossRef] 